Original article

\title{
Assessment of the bioavailability of minerals and antioxidant activity of the grain bread in the in vivo experiment
}

\author{
Nadezhda N. Alekhina, Elena I. Ponomareva, Irina M. Zharkova, Andrey V. Grebenshchikov \\ Voronezh State University of Engineering Technologies, Voronezh, Russia
}

Received 2 February 2018, Revised 18 October 2018, Accepted 25 October 2018

(C) 2018, Alekhina N.N., Ponomareva E.I., Zharkova I.M., Grebenshchikov A.V

(C) 2018, Russian Open Medical Journal

\begin{abstract}
The aim of the study was to determine the bioavailability of minerals and oxidation-antioxidant status in the laboratory animals fed with bread from regular and bioactivated wheat grain.

Material and Methods - Studies were conducted for 21 days on white inbred BALB/c mice. The animals were organized in three groups with 30 mice in each one. Group 1 (control group) was given the complete compound feed; Group 2 was fed with regular whole wheat bread; and Group 3 was given the bread from the bioactivated wheat grain. Their blood plasma was tested for total protein, cholesterol, glucose, low and high density lipoproteins, phosphorus, calcium, magnesium, iron, zinc, malondialdehyde (MDA) levels, and the activity of superoxide dismutase (SOD). Calcium was detected histochemically using McGee-Russell's method with Alizarin red S.

Results - It was established that the levels of glucose, total protein, cholesterol, and lipids in the blood plasma of animals in all groups were within the physiological norms. There were no significant reliable deviations in the levels of mineral substances in the blood plasma of the animals in the study groups. However, the histochemical response of the bone tissue calcium to the Alizarin red S revealed significant differences in its content in the tissues between the animals of the three groups. At the $21^{\text {st }}$ day of the experiment, the maximum light absorption of the colored specimen was observed in Group 3 which indicated higher calcium content in the bone tissue of the animals fed with the bread from the bioactivated wheat grain. The oxidation-antioxidant status of the animals in Groups 2 and 3 was higher than that of the control group. On the $21^{\text {st }}$ day of the experiment, MDA content in the blood plasma of the animals in Group 3 was $0.04 \pm 0.017 \mathrm{mmol} / \mathrm{L}$ which is 2.0 and 1.5 times less as compared to Groups 1 and 2 respectively. The activity of SOD in the blood plasma on the $21^{\text {st }}$ day of the experiment was the highest in Group 3 animals.

Conclusion - The experiment on the laboratory mice has shown that the use of the bread from the bioactivated wheat grain makes it possible to improve the bioavailability of minerals and increase the antioxidant activity of blood plasma.
\end{abstract}

Keywords: bioactivated wheat grain, antioxidant activity, bioavailability, minerals, laboratory mice, bread.

Cite as Alekhina NN, Ponomareva El, Zharkova IM, Grebenshchikov AV. Assessment of the bioavailability of minerals and antioxidant activity of the grain bread in the in vivo experiment. Russian Open Medical Journal 2018; 7: e0409.

Correspondence to Nadezhda N. Alekhina. Address: Department of Bakery, Confectionery, Pasta and Grain Processing Technologies, Voronezh State University of Engineering Technologies, 19, Revolution Avenue, Voronezh, 394036, Russia. E-mail: nadinat@yandex.ru.

\section{Introduction}

Today the shortage of minerals in human nutrition is a serious problem not only for developing countries, but also for economically developed ones [1]. Cereals and legumes constitute a significant part of the food [2].

Whole grain cereals contain phytic acid and its salt, phytin. In the human body, they form insoluble compounds with vital minerals, such as phosphorus, calcium, magnesium, iron, and zinc, which prevents their absorption [1, 3-5].

For people who eat plant food, phytic acid and its salts become the main cause of mineral deficiency, which subsequently leads to problems with teeth, rickets, osteoporosis, and digestive disorders $[6,7]$. Therefore, in order to prevent osteoporosis, possible musculoskeletal disorders (especially in the elderly people) and bone fractures, including femur fractures, it is necessary to reduce the anti-nutritional effect of phytin $[2,8]$. One way to reduce the content of phytic acid and its salts is germination (bioactivation) of grain $[2,9]$.

In recent years, domestic and foreign scientists have been actively studying the effects of antioxidants on human health since oxidative stress is the cause of most cardiovascular, neurodegenerative, endocrine and other diseases $[10,11]$. In the human body, the endogenous synthesis of antioxidants depends on their intake with food [12]. The low-antioxidant foods predominance in the diet can lead to the failure of the antioxidant body protection system.

For humans, the effectiveness of new products can be predicted at the stage of preclinical testing. Therefore, clinical approbation of products has to be preceded by preclinical studies. 
Table 1. Body weight dynamics of laboratory mice ( $n=\mathbf{3 0}$ in each group)

\begin{tabular}{|c|c|c|c|c|}
\hline \multirow[t]{2}{*}{ Parameter } & \multirow[t]{2}{*}{ Day of the experiment } & \multicolumn{3}{|c|}{ Values for mice in different groups } \\
\hline & & Group 1 & Group 2 & Group 3 \\
\hline \multirow[t]{3}{*}{ Weight, g } & 0 & $7.9 \pm 0.5$ & $7.6 \pm 0.4$ & $7.7 \pm 0.4$ \\
\hline & 11 & $12.1 \pm 1.3$ & $14.3 \pm 0.9$ & $17.6 \pm 1.2$ \\
\hline & 21 & $17.4 \pm 1.3$ & $19.7 \pm 1.1$ & $21.8 \pm 0.7$ \\
\hline \multirow[t]{3}{*}{ Growth, \% } & 0 & - & - & -1 \\
\hline & 11 & $53.2 \pm 5.4^{*}$ & $88,2 \pm 3,5^{*}$ & $128.6 \pm 4.1^{*}$ \\
\hline & 21 & $120.3 \pm 6.2 *$ & $159,2 \pm 4,8^{*}$ & $183.1 \pm 5.3^{*}$ \\
\hline
\end{tabular}

* Statistically significant $(p<0.05)$ difference from the initial body weight.

Table 2. Biochemical blood test for mice ( $n=30$ in each group)

\begin{tabular}{|c|c|c|c|c|c|c|c|c|c|c|}
\hline \multirow{4}{*}{$\begin{array}{l}\text { Group of } \\
\text { animals }\end{array}$} & \multicolumn{10}{|c|}{ Blood values } \\
\hline & \multirow{2}{*}{\multicolumn{2}{|c|}{ Glucose, $\mathrm{mmol} / \mathrm{L}$}} & \multirow{2}{*}{\multicolumn{2}{|c|}{ Total protein, $\mathrm{g} / \mathrm{L}$}} & \multicolumn{2}{|c|}{ Cholesterol, $\mathrm{mmol} / \mathrm{L}$} & \multicolumn{4}{|c|}{ Lipids, mmol/L } \\
\hline & & & & & & & & & & \\
\hline & beginning & end & beginning & end & beginning & end & beginning & end & beginning & end \\
\hline 1 & $4.7 \pm 0.23$ & $4.5 \pm 0.31^{*}$ & $54 \pm 1.4$ & $57 \pm 2.2^{*}$ & $2.1 \pm 0.10$ & $2.6 \pm 0.09 *$ & $0.11 \pm 0.03$ & $0.31 \pm 0.03 *$ & $0.13 \pm 0.03$ & $1.89 \pm 0.03^{*}$ \\
\hline 2 & $4.6 \pm 0.21$ & $4.6 \pm 0.15^{*}$ & $55 \pm 2.1$ & $57 \pm 1.8 *$ & $2.2 \pm 0.11$ & $2.4 \pm 0.09 *$ & $0.13 \pm 0.03$ & $0.64 \pm 0.02 *$ & $0.15 \pm 0.03$ & $1.99 \pm 0.03^{*}$ \\
\hline 3 & $4.7 \pm 0.28$ & $4.8 \pm 0.32 *$ & $55 \pm 2.0$ & $56 \pm 1.9 *$ & $2.1 \pm 0.11$ & $2.3 \pm 0.10^{*}$ & $0.12 \pm 0.01$ & $0.69 \pm 0.03 *$ & $0.14 \pm 0.03$ & $2.07 \pm 0.03^{*}$ \\
\hline
\end{tabular}

* Statistically significant $(p<0.05)$ difference between the indicators at the beginning and at the end of the experiment.

The main biological link in the experiment is laboratory animals. The results of the research on animals are crucial for filling the gaps in the knowledge about human health and diseases. Animal studies are needed to solve the following problems: to assess the absorption of minerals; to determine how biochemical parameters and antioxidant activity of blood plasma of mice change due to their consumption of the bread from the bioactivated wheat grain.

The aim of the studies was to determine the bioavailability of mineral substances and the oxidation-antioxidant status of the laboratory animals fed with bread prepared from regular and bioactivated wheat grain.

\section{Material and Methods}

For the study, two experimental and one control group containing 30 white inbred $B A L B / C$ mice each were formed. The mice were 15 days old with the initial body weight of $7.7 \pm 0.4 \mathrm{~g}$ (data presented as mean with standard deviation).

All applicable international, national and/or institutional guidelines for the care and use of animals were complied with. All procedures conducted in studies involving animals conformed to the ethical standards of the institution or the practice where the studies were conducted $[13,14]$.

The animals from Group 1 (control) were fed with granulated complete compound feed. In the experimental groups, mice were given bread instead of the compound feed: in Group 2, regular whole wheat bread, and in Group 3, the bread from the bioactivated (germinated) wheat grain. During the experiment, 300 -grams bread loafs were baked every three days, cut into slices, and natural dried.

The weight of the feed per a mouse was calculated according to the GOST R 50258-92 "Complete compound feeds for laboratory animals". Water was provided without restrictions. The duration of the experiment was 21 days. The amount of the feed consumed was calculated as the difference between the feed given and the feed actually eaten. Throughout the experiment, the mice in all groups were weighed daily. Based on the results obtained, the increments to the primary data were calculated.
Blood taken from the tail vein before and after the experiment was tested for total protein $(\mathrm{g} / \mathrm{L})$, cholesterol $(\mathrm{mmol} / \mathrm{L})$, glucose (mmol/L), low density lipoproteins (LDL) and high density lipoproteins (HDL) (mmol/L), phosphorus $(\mathrm{mmol} / \mathrm{L})$, calcium $(\mathrm{mmol} / \mathrm{L})$, magnesium $(\mathrm{mmol} / \mathrm{L})$, iron $(\mathrm{mmol} / \mathrm{L})$, and zinc $(\mathrm{mmol} / \mathrm{L})$. Malondialdehyde (MDA) level was measured through the reaction with thiobarbituric acid [15], and superoxide dismutase (SOD) activity was measured through inhibition of the reduction of nitrous tetrazolium $[16,17]$.

Calcium was detected histochemically using McGee-Russell's method with Alizarin red $\mathrm{S}$ on tissue specimens obtained from the fragment of the last caudal vertebra by the incisional biopsy (partial excision) $[18,19]$. The biopsy specimens were fixed in alcoholic formalin and dehydrated in ascending alcohols. Then they were compacted in Histomix medium and cut into thin sections. Simultaneously with the histochemical treatment, the mice bone tissue specimens were stained using a classical technique with hematoxylin-eosin at the age of 15 days, and with thionine and picric acid at the age of 21 days [20]. The images were taken and analyzed with the Altami Studio software installed on the Altami Bio-1 microscope [21].

Statistical processing of the experimental data and graphs plotting were carried out in Microsoft Excel 2010 (Microsoft Corp., USA). Kolmogorov-Smirnov criterion was used to test the experimental data distribution for normality. All the parameters considered in the study were normally distributed. The comparison of the sample arithmetic means was carried out with Student's t-test. Cochran's criterion was used to test the reproducibility of the experiments. The critical level of significance (p) in testing statistical hypotheses was assumed to be 0.05 . Quantitative data in the article have the format of $M \pm S D$ where $M$ is the mean value and SD is the standard deviation.

\section{Results}

Monitoring of the food intake by the experimental animals showed that animals in Groups 2 and 3 ate more feed than in control Group 1 by $7.4 \pm 0.5 \%$ and $9.1 \pm 0.7 \%$ respectively. 
Table 3. The content of macro- and microelements in the blood of the mice ( $\mathbf{n}=\mathbf{3 0}$ in each group)

\begin{tabular}{|c|c|c|c|c|c|c|c|c|c|c|}
\hline \multirow{3}{*}{$\begin{array}{l}\text { Group of } \\
\text { animals }\end{array}$} & \multicolumn{10}{|c|}{ Content in blood, $\mathrm{mmol} / \mathrm{L}$} \\
\hline & \multicolumn{2}{|c|}{ Phosphorus } & \multicolumn{2}{|c|}{ Calcium } & \multicolumn{2}{|c|}{ Magnesium } & \multicolumn{2}{|c|}{ Iron } & \multicolumn{2}{|c|}{ Zinc } \\
\hline & beginning & end & beginning & end & beginning & end & beginning & end & beginning & end \\
\hline 1 & $0.8 \pm 0.03$ & $0.9 \pm 0.03 *$ & $2.0 \pm 0.13$ & $2.1 \pm 0.13$ & $0.8 \pm 0.11$ & $0.8 \pm 0.11$ & $8.7 \pm 0.49$ & $9.1 \pm 0.61^{*}$ & $36.3 \pm 2.22$ & $36.0 \pm 2.22$ \\
\hline 2 & $0.8 \pm 0.03$ & $0.9 \pm 0.03 *$ & $1.9 \pm 0.13$ & $2.1 \pm 0.13^{*}$ & $0.8 \pm 0.11$ & $0.9 \pm 0.11 *$ & $8.5 \pm 0.61$ & $9.0 \pm 0.62 *$ & $34.8 \pm 2.22$ & $35.9 \pm 2.22 *$ \\
\hline 3 & $0.9 \pm 0.03$ & $0.9 \pm 0.03$ & $1.9 \pm 0.13$ & $2.1 \pm 0.13^{*}$ & $0.8 \pm 0.11$ & $0.8 \pm 0.11$ & $8.7 \pm 0.58$ & $9.1 \pm 0.62 *$ & $35.2 \pm 2.22$ & $35.8 \pm 2.22 *$ \\
\hline
\end{tabular}

* Statistically significant $(\mathrm{p}<0.05)$ difference between the indicators at the beginning and at the end of the experiment.

Table 4. Cytophotometric characteristic of histochemical reaction of mice bone tissue

\begin{tabular}{ccc}
$\begin{array}{c}\text { Group of } \\
\text { animals }\end{array}$ & $\begin{array}{c}\text { The light absorption of the bone tissue stained with Alizarin } \\
\text { red S at the beginning and at the end of the experiment, a.u. } \\
\text { beginning }\end{array}$ \\
\hline 1 & $1.31 \pm 0.155$ & $1.70 \pm 0.087^{*}$ \\
2 & $1.32 \pm 0.099$ & $1.89 \pm 0.044^{*}$ \\
3 & $1.31 \pm 0.112$ & $2.07 \pm 0.079^{*}$
\end{tabular}

* Statistically significant $(p<0.05)$ difference between the indicators at the beginning and at the end of the experiment. a.u., arbitrary units.

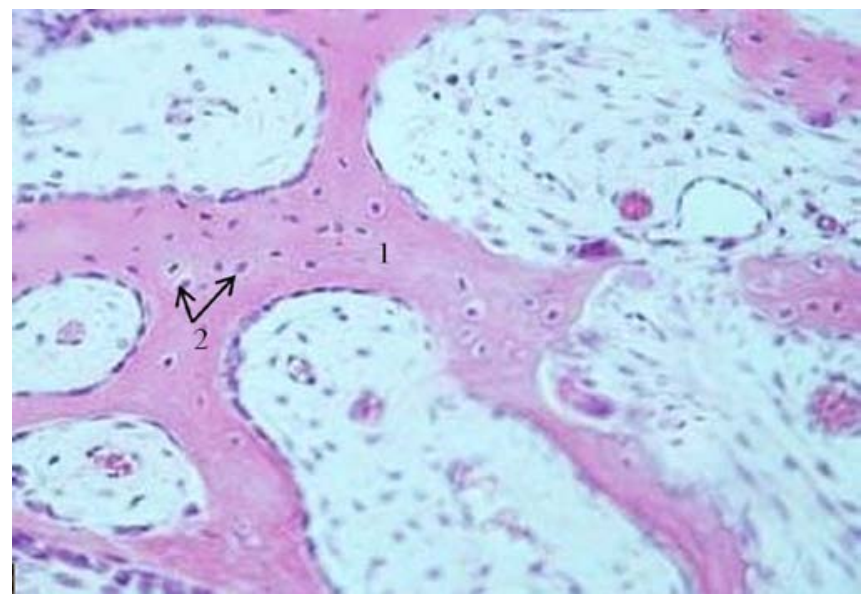

Figure 1. Microstructure of coarse-fibrous immature bone tissue $(\times 100)$ : 1 - intercellular substance of bone; 2 - osteocytes (stained with hematoxylin-eosin).

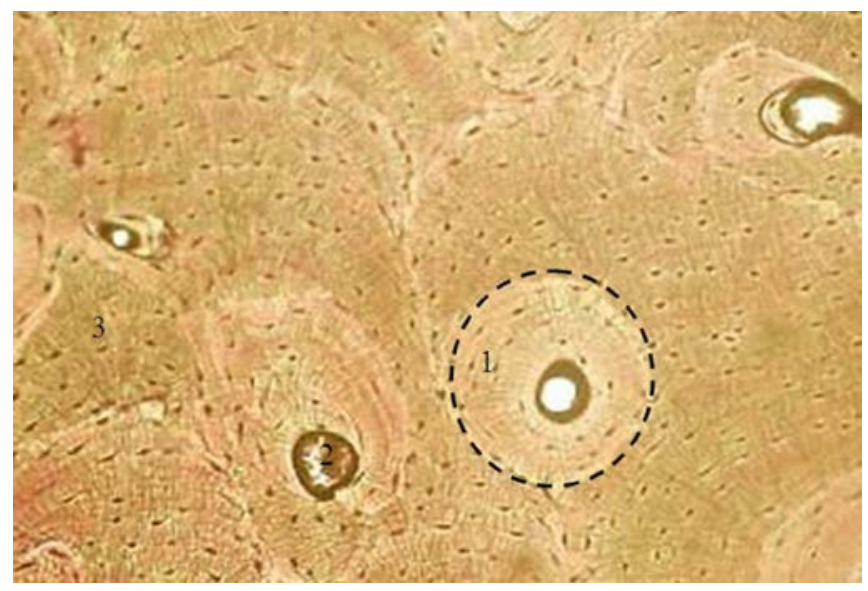

Figure 2. Microstructure of mature bone tissue of animals in Group 3 on the $21^{\text {st }}$ day of the experiment $(\times 100): 1$ - osteon; 2 - osteon channel (Haversian canal); 3 - intercalary bone plates (stained with thionine and picric acid).
Table 5. The activity of superoxide dismutase and the level of malondialdehyde in the animals

Group of Values at the beginning and at the end of the experiment

animals $\quad$ Superoxide dismutase, $\mu \mathrm{M}$ formazan / mg protein / $\mathrm{min}$

\begin{tabular}{l|ll} 
beginning & end & beginning end
\end{tabular}

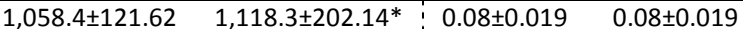

$\begin{array}{lll:lll}1 & 1,058.4 \pm 121.62 & 1,118.3 \pm 202.14 & 0.08 \pm 0.019 & 0.08 \pm 0.019 \\ 2 & 1,101.3 \pm 114.07 & 1,986.4 \pm 120.11 * & 0.09 \pm 0.016 & 0.06 \pm 0.019 *\end{array}$

$\begin{array}{llllll}3 & 1,093.4 \pm 109.15 & 2,056.9 \pm 146.31 * & 0.09 \pm 0.018 & 0.04 \pm 0.017^{*}\end{array}$

* Statistically significant $(p<0.05)$ difference between the indices between the indicators at the beginning and at the end of the experiment.

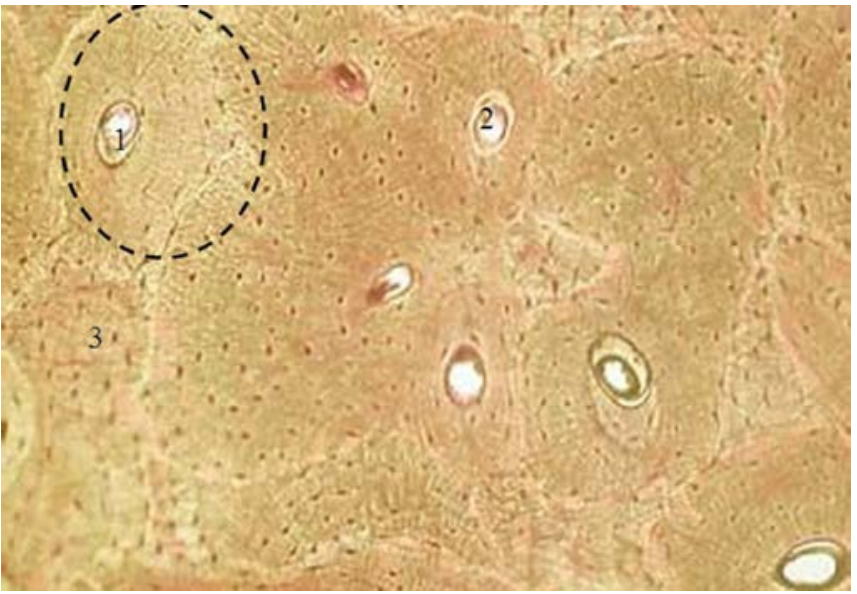

Figure 3. Microstructure of mature bone tissue of the animals in the control group on the $21^{\text {st }}$ day of the experiment $(\times 100)$ : 1 - osteon; 2 osteon channel (Haversian canal); 3 - intercalary bone plates (stained with thionine and picric acid).

The animals developed with almost equal intensity without any visible deviations. Survival rate over the observation period was $100 \%$ in all groups. By the 21st day of the experiment, the highest increase in the mice body weight was recorded for Group 3 (183.1\%, $\mathrm{p}=0.042$ ) (Table 1).

In addition to monitoring animals' growth, their clinical biochemical status was checked for a number of indicators throughout the experiment (Table 2).

The tests showed that the glucose level in the blood fluctuated insignificantly within the limits of the physiological norm. By the end of the experiment, the highest glucose level in the blood plasma was recorded for the animals in Group 3, which were fed with the bread from the bioactivated wheat grain, and it was $6.7 \%$ $(p=0.015)$ higher than the blood glucose level of the animals in the control group.

The total protein level in all analyzed blood samples did not exceed the limits of physiological norm and averaged $55.5 \mathrm{~g} / \mathrm{L}$ in all groups. 
The cholesterol levels on the $21^{\text {st }}$ day of the experiment in the control group approached the upper limit of the physiological norm $(2.7 \mathrm{mmol} / \mathrm{L})$ and amounted to $2.6 \pm 0.1 \mathrm{mmol} / \mathrm{L}$, which is $8.3 \%$ and $13.0 \%$ ( $p=0.023$ ) higher than in Groups 2 and 3 respectively.

The LDL level was also within the physiological norm and did not exceed $3 \mathrm{mmol} / \mathrm{L}$. HDL levels, on average, increased 14.2 times in all groups $(\mathrm{p}=0.034)$ (Table 2$)$.

During the experiment, the content of some macro- and microelements was monitored (Table 3). No significant deviations in the levels of phosphorus, calcium, magnesium, iron, and zinc in the blood plasma of animals in Groups 2, 3 and 1 (control group) were observed. However, comparison of the values at the beginning of the experiment and after 21 days revealed certain differences. Specifically, by the $21^{\text {st }}$ day of the experiment, the level of phosphorus in the plasma of animals increased on average by $8.3 \%$; calcium, by $8.7 \%$; magnesium, by $4.2 \%$; and iron, by $5.0 \%$ $(p=0.028)$ as compared to the values before the feeding. The level of zinc marginally decreased in the control group by $0.8 \%$, and in Groups 2 and 3, on the contrary, it slightly increased by $3.2 \%$ and $1.7 \%(p=0.042)$ respectively.

Throughout the observation period, the clinical state of mice in all groups remained normal. There were no abnormalities in their behavior or health.

The calcium content in the bone tissue of animals in all groups was studied histomorphologically. In 15 days old mice, the ossein fibers in the bone fragment did not have an orderly arrangement as in mature bone tissue. Most of the detected typical cells were surrounded by the intercellular substance. They were located on the surface of the bone and around the blood vessels that pierce the bone. This cell distribution within the specimen was typical for all samples obtained from animals of this age (Figure 1 ).

The ossein fibers in the bone tissue samples taken from the animals of all groups on the $21^{\text {st }}$ day were arranged orderly which promoted the formation of bone plates (Figures 2 and 3). Osteon fibers were arranged similarly. The Haversian system of the compact bone consisted of parallel fibers with osteocytes and osteoblasts localized in special lacunae and around Haversian canals piercing the bone. The cells had processes that ensured their contact with each other.

The analysis of the microstructure revealed some differences in the bone tissue formed by the $21^{\text {st }}$ day of the experiment. The bone tissue of the mice fed with the bread from the bioactivated wheat grain had stronger disconnected osteons while the osteons of the bone tissue in the control group were significantly smaller.

Histochemical reaction of the bone tissue calcium with Alizarin red $\mathrm{S}$ showed significant differences in its content in the tissues of animals in different groups (Table 4).

At the beginning of the experiment, the light absorption of stained calcium chelate compounds with Alizarin red $\mathrm{S}$ in the bone tissue specimens did not have any significant differences and averaged $1.31 \pm 0.211 \mathrm{AU}$. However, on the $21^{\text {st }}$ day of the experiment the cytophotometric analysis of the histochemical reaction with Alizarin red $S$ in the bone specimens showed substantial differences. Specifically, on the 21st day of feeding, the value of the parameter in question increased by $29.8 \%$ in the bone tissue preparations in the control group; by $43.2 \%$, in Group 2; and by $58.0 \%$, in Group 3 ( $p=0.039$ ).

To study the processes of lipid peroxidation (LPO) in animals fed with the regular whole wheat bread and the bread from the bioactivated wheat grain, the activity of the antioxidant protection enzyme, superoxide dismutase (SOD), was measured. To assess the intensity of LPO, malondialdehyde (MDA) was tested (Table 5).

At the initial stage of the experiment, there were no significant differences in the values of SOD and MDA between animals. On the $21^{\text {st }}$ day of feeding, a significant quantitative difference in LPO markers was detected. In the control group, the activity of SOD increased with age by $5.6 \%$ while in Groups 2 and 3, the activity of the enzyme increased by $80.4 \%$ and $88.1 \%(p=0.047)$ respectively. The level of MDA in animals of the control group did not change. At the same time, MDA significantly decreased by $55.5 \%(p=0.031)$ in Group 3. The level of MDA in Group 3, where animals were fed with the bread from the bioactivated wheat grain, was more than $50 \%$ lower $(p=0.024)$ than in the control group.

\section{Discussion}

The comparative data on the dynamics of weight gain of animals in the control group and in the experimental groups as well as the values of the clinical biochemical parameters of the blood plasma of white inbred BALB/C mice indicate significant effectiveness of the diet containing the bread from the bioactivated wheat grain.

The analysis of the bone tissue microstructure proved that structural units of bones and connective tissue in the mice of Group 3 were formed earlier than in that of the control group. Changes in the calcium content in the bone tissue can be explained by the formation of bone tissue with age and the gradual deposition of calcium salts in it. The higher content of calcium in the bone tissue of the animals in Group 3 is related to the consumption of the bread from the bioactivated wheat grain as grain germination improves calcium bioavailability. Germination activates phytase which hydrolyzes phytin with formation of inositol and phosphoric acid salts. The subsequent phosphoric acid salts dissociation and formation of residues and metal ions (phosphorus, calcium, magnesium, iron, and zinc) improve mineral absorption in the body [22]. The experimental data obtained are consistent with the results of the studies by foreign scientists. Azeke, Baruah, et al. proved that germination of wheat grain increases phosphorus content and its availability for the bone growth $[2,23]$. The increase in the bioavailability of iron in the germinated grains is demonstrated in the works of Nielsen et al. [1]. Bohn et al. studied how mineral bioavailability of various foods, including bread, can be improved by the use of exogenous phytases of fungal origin [7].

We have proved that the bioavailability of mineral substances of the whole wheat bread can be increased by pre-treatment (germination) of the wheat grain due to the reaction of endogenous phytases with phytin.

In the organism of the animals in Group 3, the activity of superoxide dismutase was the highest and the level of malondialdehyde was the lowest because effective antioxidants, such as bioflavonoids, vitamin $\mathrm{E}$, and zinc, produced during the wheat grain bioactivation process boosted the antioxidant system of the animal body.

\section{Conclusion}

The experimental data show that the bread from the bioactivated wheat grain is richer in bio-absorbable mineral substances and powerful antioxidants that boost the animal body's 
antioxidant system. It is recommended that people, especially the elderly, include such bread in their diet to reduce the risk of osteoporosis and cardiovascular diseases.

\section{Funding}

The study was produced with the financial support provided by the Ministry of Education and Science of the Russian Federation for applied research under the federal target program "Research and Development in Priority Areas of Development of the Russian Scientific and Technological Complex for 2014-2020", grant agreement No. 14.577.21.0256, September 26, 2017, unique identifier ASRED RFMEFI57717X0256.

\section{Conflict of interest}

The authors state that they have no conflict of interest.

\section{References}

1. Nielsen AV, Tetens I, Meyer AS. Potential of phytase-mediated iron release from cereal-based foods: a quantitative view. Nutrients 2013; 5(8): 3074-3098 https://doi.org/10.3390/nu5083074.

2. Azeke MA, Egielewa SJ, Eigbogbo MU, Ihimire IG. Effect of germination on the phytase activity, phytate and total phosphorus contents of rice (Oryza sativa), maize (Zea mays), millet (Panicum milliaceum), sorghum (Sorghum bicolor) and wheat (Triticum aestivum). J Food Sci Technol 2011; 48(6): 724-729. https://doi.org/10.1007/s13197-0100186-y.

3. Kumar V, Sinha AK, Makkar HPS, Becker K. Dietary roles of phytate and phytase in human nutrition: a review. Food Chemistry 2010; 120(4): 945-959. https://doi.org/10.1016/j.foodchem.2009.11.052.

4. Dost K, Tokul O. Determination of phytic acid in wheat and wheat products by reverse phase high performance liquid chromatography. Anal Chim Acta 2006; 558(1-2): 22-27. https://doi.org/10.1016/j.aca.2005.11.035.

5. Van Way III CW, Ireton-Jones C. Nutrition Secrets. Moscow-SPb, Russia: Publishing house BINOM \& Publishing house Dialect, 2006; 320 p. Russian.

6. Matkovic V, Ilich JZ. Calcium requirements for growth: are current recommendations adequate? Nutr Rev 1993; 51(6): 171-180. https://doi.org/10.1111/j.1753-4887.1993.tb03097.x.

7. Bohn L, Meyer AS, Rasmussen SK. Phytate: impact on environment and human nutrition. a challenge for molecular breeding. J Zhejiang Univ Sci B 2008; 9(3): 165-191. https://doi.org/10.1631/jzus.B0710640.

8. Tutelyan VA, Spirichev VB, Sukhanov BP. Micronutrients in the diet of a healthy and sick person. Moscow, Russia: Kolos, 2002; 424 p. Russian. https://elibrary.ru/item.asp?id=21456221.

9. Gibson RS, Perlas L, Hotz C. Improving the bioavailability of nutrients in plant foods at the household level. Proc Nutr Soc 2006; 65(2): 160-168. https://doi.org/10.1079/PNS2006489.

10. Galkina OV, Putilina FE, Romanova AA, Eshchenko ND. Changes in lipid peroxidation and antioxidant system of the brain during early postnatal development in rats. Neurochem J 2009; 3(2): 93-97. https://doi.org/10.1134/S1819712409020032.

11. Okunevich IV, Sapronov NS. Antioxidants: the effectiveness of natural and synthetic compounds in complex therapy of cardiovascular diseases. Reviews on Clinical Pharmacology and Drug Therapy 2004; 3(3): 2-17. Russian. https://elibrary.ru/item.asp?id=9288234.

12. Nilova LP, Pilipenko TV. Evaluation of antioxidant properties of enriched bakery products in experiments on laboratory animals. Issues of Nutrition 2016; 85(6): 39-47. Russian. https://elibrary.ru/item.asp?id=27633360.

13. European convention for the protection of vertebrate animals used for experimental and other scientific purposes. Strasbourg, 1986. https://rm.coe.int/168007a67b.

14. Borisenko EA, Kishore YuK. Biological ethics: collection of normative documents on conducting biomedical research with animals. Novosibirsk, Russia: Novosibirsk State Agrarian University, 2015; 91 p.
Russian. http://docplayer.ru/59790132-Biologicheskaya-etika-sborniknormativnyh-dokumentov-po-provedeniyu-mediko-biologicheskihissledovaniy-s-ispolzovaniem-zhivotnyh.html.

15. Rogozhin VV, Kurylyk TT, Kershengolts BM. The method of determining the concentration of malondialdehyde using thiobarbituric acid. Patent No. 2112241, RU. Appl. 08.09.1995; Publ. 27.05.1998. http://www.freepatent.ru/patents/2112241.

16. Smirnova LP, Kondakova IV, Borunov EV. Method for determining the activity of superoxide dismutase. Patent No. 2272074, RU. Appl. 13.08.2004; Publ. 20.03.2006. http://www.freepatent.ru/patents/2272074.

17. Dotsenko OI, Dotsenko AV, Mishchenko AM. Activity of superoxide dismutase and catalase in erythrocytes and some tissues of mice under conditions of low frequency vibration. Physics of Alive 2010; 18(1) 107-113. Rusian. https://elibrary.ru/item.asp?id=21567693.

18. Selivanov EV. Dyes in biology and medicine: a handbook. Barnaul, Russia: Azbuka, 2003; $40 \quad$ p. $\quad$ Russian. http://molbiol.ru/forums/uploads/lit/Krasiteli_v_biologii_i_medicine.pdf.

19. Lillie RD. Histopatologic technic and practical histochemistry. McGrawHill, New York: Blakiston Division, 1965; 715 p. https://books.google.ru/books?id=UVprAAAAMAAJ\&hl=ru\&source=gb s book other versions.

20. Methods of morphological research. Handbook. Voronezh, Russia: Publishing House of All-Russian Scientific Research Veterinary Institute of Pathology, Pharmacology and Therapy, 2007; 88 p. Russian. https://elibrary.ru/item.asp?id=21276114.

21. Agroskin LS, Papayan GV. Cytophotometry. Equipment and methods for analysis of cells by absorption. Leningrad, USSR: Nauka, 1977; 295 p. Russian. https://www.twirpx.com/file/1647556.

22. Schlemmer U, Frølich W, Prieto RM, Grases F. Phytate in foods and significance for humans: food sources, intake, processing, bioavailability, protective role and analysis. Mol Nutr Food Res 2009; 53 Suppl 2: S330-S375. https://doi.org/10.1002/mnfr.200900099.

23. Baruah K, Sahu NP, Pal AK, Debnath D, Yengkokpam S, Mukherjee SC. Interactions of dietary microbial phytase, citric acid and crude protein level on mineral utilization by Rohu, Labeo rohita (Hamilton), Juveniles. Journal of World Aquaculture Society 2007; 38(2): 238-249. https://doi.org/10.1111/j.1749-7345.2007.00092.x.

\section{Authors:}

Nadezhda N. Alekhina - PhD, Assistant Professor, Department of Bakery, Confectionery, Pasta and Grain Processing Technologies, Voronezh State University of Engineering Technologies, Voronezh, Russia. https://orcid.org/0000-0002-3317-9858.

Elena I. Ponomareva - PhD, Professor, Department of Bakery, Confectionery, Pasta and Grain Processing Technologies, Voronezh State University of Engineering Technologies, Voronezh, Russia. https://orcid.org/0000-0003-2310-2838.

Irina M. Zharkova - PhD, Assistant Professor, Department of Bakery Confectionery, Pasta and Grain Processing Technologies, Voronezh State University of Engineering Technologies, Voronezh, Russia. https://orcid.org/0000-0001-8662-4559.

Andrey V. Grebenshchikov - PhD, Assistant Professor, Department of Animal Origin Food Technology, Voronezh State University of Engineering Technologies, Voronezh, Russia. https://orcid.org/0000-0002-0443-9809. 